\title{
The Israeli Moshav in Nigeria: An Estimate of Returns ${ }^{*}$
}

\author{
JeROME C. WeLLS
}

\begin{abstract}
This article provides an estimate of prospective social returns to the Israeli form of agricultural-settlement unit introduced into Western Nigeria in 1961. Evaluation is based on FAO data covering 13 farm-settlement units and including 19 crop and livestock-raising activities. Benefit-cost analysis is used to determine whether the project meets the minimum criteria applied to investment components of the 1962-1968 Nigerian Development Plan, and the evaluative framework is designed (a) to isolate cases where the project can be judged without recourse to measurement of external benefits from those cases where such estimation is required, and (b) to permit examination of the effects on estimated returns resulting from different assumptions about product and factor prices. If the FAO projections of product prices and the government wage and borrowing rates are used as a basis for evaluation, the project appears to be a justifiable component of the National Development Plan; this conclusion is severely weakened when the product- and factor-price assumptions are examined. Acceptability of the project is found to be very sensitive to the possibility of capital rationing and to rather tenuous assumptions about the prices of cocoa and poultry products. Finally it is noted that the rapid expansion of the project leaves it open to substantial losses if the technical assumptions about inputs and yields prove incorrect.
\end{abstract}

$\mathrm{T}$

IHE Israeli cooperative agricultural settlement, the Moshav, has recently become a widely emulated form of agricultural investment in underdeveloped countries. Its form of organization, resting on the cooperative management of individual holdings and the central provision of mechanical and marketing services, proves attractive to both agricultural planners and local politicians as a means of introducing modern agricultural techniques and of better integrating traditional peasant farming into the market economy. Partly as a result of the wide dissemination of Israeli technical aid, Moshav-inspired settlements are being established in many countries, particularly in sub-Saharan Africa. ${ }^{1}$

Although the influence of the Moshav on government agricultural investment has been widely noted, there has been little discussion of the potential economic returns to this form of organization, especially in the context of African agriculture. Cost studies have been made, but these

* This article is drawn from my doctoral dissertation on agricultural investments in the Federation of Nigeria's 6-year development program [10]. The study on which it is based was made possible by a Ford Foundation Dissertation Grant and a grant under the Ford Foundation's Nigeria Project. I am grateful to the Nigerian Western Region Ministry of Agriculture and Natural Resources and the Farm Settlement

Jerome C. Wells is research fellow, Center for Research on Economic Development, University of Michigan and Nigerian Institute of Social and Economic Research. 
have focused on returns to the individual settler and have left the issue of the Moshav's validity as an investment component of a development plan a matter of some debate. This study uses a limited measure of social returns to evaluate the Moshav-inspired settlement program introduced in two regions of Nigeria as part of her first Six-Year Development Plan. The evaluative test applied rests on benefit-cost analysis and is consistent with the overall criteria of investment allocation applied in the Six-Year Plan. Data for the analysis are drawn from estimates of costs and yields made by an FAO team providing technical assistance to the settlement program.

\section{Nature and Goals of the Farm Settlement Program}

The program in question constitutes the largest single agricultural outlay of the 1962-1968 National Plan and, at an estimated capital outlay of about $\& 5 \%$ million, it is expected to comprise about 6 percent of the regional government's capital outlay during the plan period. ${ }^{2}$

It combines investment in the direct production of crops and livestock with an experiment in the training of farmers, their resettlement under new patterns of land tenure, and the introduction of new techniques and patterns of cropping. Thirteen settlements of 100 and 200 farm families are being established on surplus land acquired from local chiefs or native authorities. Each settler family holds a unit of 15-50 acres consisting of several cash crops, a garden plot, and one or two types of livestock. The crops and livestock raised vary from settlement to settlement and are centrally determined to reflect local conditions and to avoid overdependence on any one type of crop. Central machinery and marketing pools are established for each settlement; housing, access roads, and community facilities are provided. A series of training institutes is to give 2 years of training to prospective settlers, who are drawn from the ranks of those who leave primary and secondary school. Settlers provide some of the work in establishing their own plots and acquire their holdings through gradual repayment of the original government investment. Repayment will cover only the cost of the settler's house and establishment of his farm unit, with community facilities and the like being provided by government grant.

FAO team for their aid and cooperation, and to Professor W. F. Stolper, Dr. Ojetunji Aboyade, and Dr. Robert Adams for helpful comments and criticisms. The opinions (and errors) are, of course, my own.

${ }^{1}$ For a general discussion of Israeli aid to Africa, including aid in establishing agricultural settlements, see Mordechai E. Kreinen [6].

${ }^{2}$ The vagaries of politics have already changed the nature of the settlement program from that which was originally proposed. The form of the project discussed here is that which was accepted as part of the National Plan in early 1962; later in that year the creation of a new region in Nigeria split the program between two regional authorities. Figures presented here relate to the old Western Region program at the time when the National Plan was accepted. The origins of the settlement program are discussed by Professor Kreinen in a previous issue of this journal [5]. 
The form of the program has changed slightly since its inception; there are now to be 17 settlements, and training is shifting from the institutes to the settlements themselves. ${ }^{3}$

Although the stated objectives of the program are numerous, its major purpose is the introduction of modern and more productive agricultural techniques together with a form of organization within which these techniques can be viable. The Moshav form of organization is seen as a means of overcoming land tenure problems which block the use of new methods, and it is hoped that success of the settlement program will encourage emulation of its techniques and cooperative form of organization by private farmers. Finally, the goal of raising agricultural productivity and income has further importance as a means of absorbing the increasing numbers of persons leaving primary and secondary school, whose movement to urban centers and subsequent unemployment is a matter of increasing concern. The provision of housing and community facilities through the settlement program is intended to make agriculture appear more attractive when compared with the amenities of urban life.

\section{Procedures Used in Evaluation}

The nature of the settlement program with its numerous goals creates a formidable task of project evaluation, which is complicated by the haste with which initial surveys for the program had to be prepared. An initial survey was made by the Western Region's Ministry of Agriculture and Natural Resources in 1959-60; this was followed by a more thorough study of individual crops and settlement units prepared by the FAO, which followed the lines of the earlier survey and focused its attention on the returns to the settler participants. ${ }^{4}$ The FAO study provides the best estimate of expected inputs and yield requirements and serves as the basis for all calculations presented here. Perhaps its only weakness is a failure to examine the potential organizational cost of welding the diverse producing activities into a viable program. ${ }^{5}$

The task of evaluation can be divided into three parts. First is the provision of adequate technical data about expected costs and yields, a task performed by the FAO survey. Second is the selection of an overall measure of project effectiveness which takes into account the stated goals of

'A good description of the original arrangements for the program can be found in Kreinen [5]. Several current studies at the Nigerian Institute of Social and Economic Research are exploring the operation of the settlement scheme.

"An FAO team of consultants was called in to run a more thorough estimate of costs and yields and to aid in the initial stages of setting up the program. They arrived late in 1960 and most estimates were prepared while the program was being set up in 1961 and 1962.

This issue constitutes a major problem in any preinvestment survey of settlement returns. 
the program without presuming that they will be achieved, and which permits some comparison with other investments in the framework of the National Development Plan. Finally, it is necessary to identify the nontechnical assumptions upon which the estimate of settlement effectiveness rests. This task involves examining the implications of ambiguous price projections-for both products and factors of production-on the measure of returns calculated in the second step.

The selection of an overall measure of project effectiveness (step 2) involves two major problems. The first of these arises from the importance attached to indirect returns, which are supposed to be achieved by the form of organization and the "demonstration effects" of the program. The multiple goals of the settlement scheme include a number of such indirect effects, most of them relating to emulation of the settlement form of organization by other farmers and a subsequent slowing of migration from rural to urban areas. These effects are cited as reasons justifying the rather sizable social-overhead component of settlement costs and are the subject of considerable dispute between groups of planners involved in appraising the project. Potentially, these effects are significant, but they defy quantitative estimation and cannot be assumed to exist per se. ${ }^{6}$ The approach to analysis taken here attempts to establish the conditions necessary for such effects to exist and the conditions under which they are crucial to justification of the settlement program. It rests on a distinction between the costs of directly productive activities (DPC), such as raising crops or livestock, and the social overheads (SOC), such as housing and settler-training costs required for the settlement form of organization. It is assumed that unless direct benefits (DB) in the form of returns to crops and livestock cover the costs directly attributable to their production (DPC), there will be no external benefits to the project. Since it is highly unlikely that farmers will emulate techniques which do not appear profitable to them, this assumption approximates a necessary-if not suffcient-condition for the presence of such benefits.

Thus, there are three possible outcomes to the test of total project returns:

(a) If DB - DPC $\geq S O C$, then the project can be said to be at least adequate under the tests of investment allocation applied in the national plan. ${ }^{\top}$

- The Ministry of Agriculture's initial estimates of returns to individual settlers erred in this respect. In recognition of the alleged indirect effects to the project, a subsidized rate of interest of $1 \frac{112}{2}$ percent was applied to all capital inputs used in the project. This procedure prejudged not only the existence of indirect effects but also their magnitude.

The test is one of investment adequacy or sufficiency, not one of optimality, for the farm-settlement program is an isolated project proposal, not one of a number of optional investments in Western Nigeria's agriculture which could be ranked. The 
(b) If $\mathrm{DB}-\mathrm{DPC}<\mathrm{O}$, external benefits are unlikely, and the project is not adequate.

(c) If $\mathrm{DB}-\mathrm{DPC}>\mathrm{O}$, but $<$ than SOC, then further examination of the possible external benefits is crucial to the justification of the settlement program.

The second issue in estimating overall project effectiveness relates to the form of criterion chosen for evaluation. The test used is a measure of social productivity which compares the discounted value of expected benefits, regardless of who receives them, with the discounted value of (social) costs of the program. The benefit-cost form of criterion is used rather than a test of returns to capital inputs because of the difficulty of defining capital inputs to the program. For components of the program such as tree crops, the capital inputs consist of labor applied in early stages of the program matched by returns when the trees reach maturity. Use of the benefit-cost form of criterion skirts the problems of defining capital at any point of time and the ambiguities involved in deriving internal rates of return on inputs at different times. It also requires that any examination of the impact of capital scarcity on the program be made through recalculating the present values of costs and returns at a higher discount rate. ${ }^{8}$

The structure of the settlement program, as well as its overall performance, can be examined by use of the benefit-cost criterion. Separate benefit-cost surveys for each crop and livestock-producing activity provide an indication of those components of the program which are most crucial to its success. Since the composition of the program is, to a limited extent, variable, it is necessary to appraise the importance of each component in the final estimate of returns.

The final step in appraising a project such as the farm-settlement program involves identifying the impact of the price assumptions on the estimate of project returns. In most cases of project analysis, projections of prices into the future are highly uncertain and a single overall estimate of project returns hides a number of tenuous assumptions about the behavior of future prices and patterns of factor scarcity. By determining the sensitivity of expected project returns to alternative price projections, the significance of these assumptions can be appraised.

Product-price assumptions for the settlement program-involving 19 different crop and livestock-producing activities-are too numerous to per-

lack of feasibility studies severely restricted the range of investment choice in the National Plan.

${ }^{8}$ The social-productivity measure of investment effectiveness used is derived from Chenery's original article on the subject [1]. The various criteria which are appropriate to use are discussed by Roland N. McKean [7]; for their relation to the framework of the Nigerian plan see Jerome C. Wells [12]. 
mit detailed analysis. It is more important to identify the assumptions about product prices which are most crucial in the overall estimates of project returns, and then to explore these assumptions.

The factor prices used initially in evaluation are those applied by the planners in other investment projects comprising the National Development Plan. The discount rate used is 6 percent, and the charge for the settler's labor is approximated by the $5 / 10 \mathrm{~d}-(\$ .80)$-pcr-day rate for unskilled labor used in establishing the settlement units. ${ }^{9}$ These prices represent only one estimate of the scarcity of factors of production during the plan period. Although the overall evaluation of any project depends strongly on the particular estimates of factor scarcities made, it is impossible to determine unambiguously the appropriate factor prices until the implications of the entire development program have been appraised. Hence it is worthwhile to use several alternative sets of factor prices in the analysis of an individual project.

In the farm-settlement program, alternative price sets were used to deal with possible changes in capital scarcity caused by the development program and with the possibility of underemployment of labor in the agricultural sector. The possibility of capital rationing is approximated by the use of 10-percent and 15-percent interest rates; and an alternative wage rate of 3/-per man-day, representing an impression of the average returns to agriculture in the Western Region, is also used..$^{10}$

\section{Returns to the Program and to Settlement Composition}

The present value of net returns to directly productive activities (DBDPC) is derived in Table 1.1 This figure can be compared to the socialoverhead-cost component (SOC) to obtain an overall appraisal of expected settlement performance. Calculations are based on the planners' assumptions about labor and capital charges and on current price estimates (to be examined below) for the product outputs. ${ }^{12}$ Since the present

- The discount rate is that applied by the planners to other investment components of the 1962-1968 Development Program. The rather low figure is derived from the current cost of borrowing by the Nigerian government, on the planners assumption that shortages of complementary resources limited the capacity of the government sector to absorb more funds than it could borrow at this rate. For an elaboration of this rationale, see W. F. Stolper [8].

${ }^{10}$ This figure can best be compared with an estimate that the cost of hired labor during the cocoa cropping season is about $3 / 6 \mathrm{~d}$ to $4 /-$ per day $[4, \mathrm{p}$. 213$]$.

"Examples of the calculations for individual crops and the FAO calculations are presented-for cocoa-in the appendix.

${ }^{11}$ It is important to note that the benefits measured here include a sizable component of revenues expected by the government marketing boards for the major export crops, cocoa and oil palm products. Ostensibly such revenues constitute a stabilization fund, but the behavior of the boards in periods of price decline implies that they are merely a source of government revenues. The present values of ex-

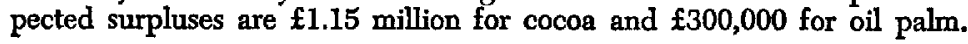


Table 1. Present value of returns to directly productive activities: 30-year settlement program

\begin{tabular}{|c|c|c|c|}
\hline Crop & Units & $\begin{array}{l}D B-D P C \\
\text { Present value } \\
\text { of net returns } \\
£ 1,000\end{array}$ & $\begin{array}{l}\text { Benefit-cost } \\
\text { ratio }\end{array}$ \\
\hline $\begin{array}{l}\text { Tree crops } \\
\text { Cocoa } \\
\text { Coffee } \\
\text { Rubber } \\
\text { Oil palm } \\
\text { Unirrigated orange } \\
\text { Unirrigated grapefruit } \\
\text { Irrigated grapefruit }\end{array}$ & $\begin{array}{c}11,050 \text { acres } \\
\text { none } \\
5,077 \text { acres } \\
13,850 \text { acres } \\
\text { none } \\
2,300 \text { acres } \\
500 \text { acres }\end{array}$ & $\begin{array}{r}1,971 \\
566 \\
600 \\
\\
282 \\
-95\end{array}$ & $\begin{array}{l}1.6 \\
.8 \\
1.35 \\
1.4 \\
1.05 \\
1.3 \\
7.5\end{array}$ \\
\hline $\begin{array}{l}\text { Field crops } \\
\text { Cassava } \\
\text { Cowpeas } \\
\text { Maize } \\
\text { Rice } \\
\text { Sorghum }\end{array}$ & $\begin{array}{r}767 \text { acres } \\
2,331 \text { acres } \\
5,368 \text { acres } \\
200 \text { acres } \\
2,331 \text { acres }\end{array}$ & $\begin{array}{r}108 \\
64 \\
219 \\
13 \\
39\end{array}$ & $\begin{array}{l}3.7 \\
1.35 \\
1.2 \\
1.1 \\
1.1\end{array}$ \\
\hline $\begin{array}{l}\text { Livestock } \\
\text { Poultry } \\
\text { Cattle (fattening) } \\
\text { Hogs }\end{array}$ & $\begin{array}{l}\text { layers } \\
4,350 \text { steers } \\
725 \text { sow }\end{array}$ & $\begin{array}{r}240 \\
76 \\
285\end{array}$ & $\begin{array}{l}1.05 \\
1.1 \\
1.25\end{array}$ \\
\hline \multicolumn{2}{|c|}{$\begin{array}{l}\text { Total } \\
\text { Plus returns from elimination of irrigated grapefruit }\end{array}$} & $\begin{array}{r}4,368 \\
95\end{array}$ & \\
\hline \multicolumn{2}{|c|}{$\begin{array}{l}\text { Present value of net returns to directly productive } \\
\text { activities }\end{array}$} & $£ 4,463$ & \\
\hline
\end{tabular}

Source: calculated from FAO's Crop and Livestock Studies [3]. Factor prices used are wage $-5 / 10 d$ per man-day, capital charge -6 percent.

value of net returns ( $\& 4.46$ million) easily covers the present value of social-overhead outlays ( $\& 3.28$ million), the settlement program passes the minimum test of investment adequacy used in the National Development Plan.

The benefit-cost ratios for particular activities provide further insight into the settlement program and its structure. The highest returns occur for cassava, the local staple crop, and with this exception, benefit-cost ratios for different activities do not vary greatly and are all relatively near 1 . Thus, judging from the expected returns to individual activities, it does not appear that the settlement form of organization will result in any dramatic increase in productivity. ${ }^{13}$ The lack of dispersion in benefit-cost ratios for different activities would seem to imply that no significant gains can be achieved by changes in the composition of crop and livestock-pro-

\footnotetext{
1s These ratios might be compared with those for an innovation in the mechanical cultivation of rice in Northern Nigeria, which range between 2.5 and 4, depending on price assumptions made [11].
} 
ducing activities. Irrigated grapefruit should be dropped from the program, ${ }^{14}$ and when expected tax revenues are considered, the major export tree crops have a slight advantage over other tree crops.

\section{The Effect of Differing Factor Scarcities}

The second step of the analytical sequence described in the preceding section is now complete. The results indicate that, on the basis of technological and price assumptions used, the settlement program can be judged as an adequate-if not spectacular-investment without recourse to any measure of indirect benefits. The third step of the sequence, examination of the factor- and product-price assumptions, tends to weaken this impression. Table 2 shows the effect of alternative assumptions about the relative factor scarcities on net returns to direct production and on estimates of settlement overhead costs.

Table 2. Present values of net returns and overhead costs at different factor-price assumptions

I. Present value of net benefits to direct production ( $£$ millions) (DB-DPC)

\begin{tabular}{lccc} 
& \multicolumn{3}{c}{ Interest rate } \\
Wage: 5/10d per man-day & $6 \%$ & $10 \%$ & $15 \%$ \\
$3 /-$ per man-day & 4.46 & 1.24 & $(-.55)$ \\
& 6.61 & 2.81 & .64
\end{tabular}

II. Present value of settlement overhead costs

\begin{tabular}{lrrr} 
& \multicolumn{3}{c}{ Interest rate } \\
Costs of direct production not allocated to par- & $6 \%$ & $10 \%$ & $15 \%$ \\
$\quad$ ticular activities & .26 & .26 & .26 \\
Social overhead: settlements & 1.26 & 1.26 & 1.26 \\
Cost of settler training: institutes & .77 & .78 & .81 \\
Resident personnel for settlement life & $\frac{.99}{3.28}$ & $\frac{.74}{3.04}$ & $\frac{.58}{2.91}$ \\
Total & $\mathbf{3 . 2 8}$ & &
\end{tabular}

Source: same as Table 1.

Direct returns to the settlement's productive activities cover their costs under all but one of the factor-price assumptions. Only in the event of severe capital rationing and high wage rates is the present value of net returns negative. The returns are, however, quite sensitive to the extent of

\footnotetext{
${ }^{14}$ Two other tree crops, coffee and unirrigated orange, were dropped from the program in the initial analysis by the Ministry of Agriculture. Coffee proved unprofitable and unirrigated orange less profitable than grapefruit, which involves identical production costs. The failure to exclude irrigated grapefruit resulted from the use of the subsidized 11/2-percent interest rate in recognition of "external benefits" to the program. It provides an example of how misspecification of such benefits can distort the structure of an investment.
} 
capital scarcity. An increase in the interest rate to 10 percent or 15 percent reduces the value of net benefits to direct production below the cost of overhead components in the program, even if the lower charge for labor inputs is assumed. In the event of more stringent conditions of capital rationing than those assumed by the planners, the settlement program could not be justified without careful examination of types of external benefits likely to result. And in this event, the extent of emulation of the settlement program would depend on estimates of returns using the higher interest rate applied in the private sector.

The optimal composition of the program is also affected by different assumptions of factor scarcity, as shown by the benefit-cost ratios presented in Table 3. Investment in tree crops is most sensitive to capital rationing, with returns to arable crops and livestock production remaining positive, if low, as capital becomes more scarce. The fact that only 2 of the 13 settlements originally planned are not based on tree crops strengthens the impression that the settlement program in its present form is justifiable only if capital is relatively cheap. The effect of capital intensity in the directly productive components of the program (tree crops) is reinforced by the presence of the large social-overhead component.

Table 3. Settlement composition: variability of benefit-cost ratios $(\mathrm{DB} / \mathrm{DPC})$ with different factor-price assumptions

\begin{tabular}{l|lll|lll}
\hline Labor charge: & \multicolumn{3}{c|}{$5 / 10 \mathrm{~d}$ per man-day } & \multicolumn{3}{c}{$3 /-$ per man-day } \\
\hline Interest rate: & $6 \%$ & $10 \%$ & $15 \%$ & $6 \%$ & $10 \%$ & $15 \%$ \\
\hline Tree crops & & & & & & \\
Cocoa & 1.6 & 1.25 & $(.9)$ & 2.0 & 1.6 & 1.2 \\
Rubber & 1.35 & 1.1 & $(.85)$ & 2.1 & 1.7 & 1.3 \\
Oil palm & 1.4 & 1.0 & $(.7)$ & 2.0 & 1.4 & $(1.0-)$ \\
Unirr. grapefruit & 1.3 & 1.05 & $(.75)$ & 1.5 & 1.25 & $(.9)$ \\
Unirr. orange & 1.05 & $(.8)$ & $(.6)$ & 1.25 & $(.95)$ & $(.7)$ \\
Coffee & $(.8)$ & $(.7)$ & $(.55)$ & 1.15 & $(.95)$ & $(.85)$ \\
Irr. grapefruit & $(.75)$ & $(.6)$ & $(.4)$ & $(.9)$ & $(.65)$ & \\
Field crops & & & & & & \\
Cassava & 3.7 & 3.7 & 3.7 & 7.2 & 7.2 & 7.2 \\
Cowpeas & 1.35 & 1.3 & 1.25 & 1.45 & 1.4 & 1.35 \\
Maize & 1.2 & 1.2 & 1.15 & 1.3 & 1.3 & 1.25 \\
Rice & 1.1 & $(1.0-)$ & $(.85)$ & 1.3 & 1.1 & $(.95)$ \\
Sorghum & 1.1 & 1.05 & 1.0 & 1.1 & 1.05 & 1.05 \\
Livestock & & & & & & \\
Hogs & 1.25 & 1.2 & 1.15 & 1.3 & 1.25 & 1.2 \\
Cattle & 1.1 & 1.0 & $(.9)$ & 1.15 & 1.05 & $(.95)$ \\
Poultry & 1.05 & 1.0 & $(.97)$ & 1.05 & 1.05 & 1.0 \\
\hline
\end{tabular}

Source: same as Table 1.

Parentheses denote benefit-cost ratios less than $1.0 ;(1.0-)$ indicates a range between .97 and 1.0 . 


\section{Product-Price Assumptions and Returns to the Program}

Estimates of returns to any investment project are heavily dependent on the assumed prices of project outputs, and the tenuousness of price assumptions introduces a large element of uncertainty into project appraisal. This is especially true in the case of the farm-settlement program, where in most cases the assumptions chosen reflect current prices modified by educated guesses about price movements in the future.

In order to determine which price assumptions are most crucial to the estimates of settlement returns derived, it is necessary to review the contribution of the various producing components. This is done in Table 4, which shows the proportion of direct benefits and net benefits from direct production (DB - DPC) contributed by each producing activity. Calculations made at the two most likely alternative factor-price sets indicate that the fortunes of the settlement program are most closely tied to cocoa and poultry. At either factor-price set, these two account for over half of the expected revenues and for almost half of the net returns to direct production. The settlement program is far more specialized than its diverse composition would indicate, and the price assumptions for cocoa and poultry products are by far the most crucial to its appraisal. Thus, the basis of

Table 4. Settlement composition: proportion of revenues and net returns contributed by productive activities

\begin{tabular}{|c|c|c|c|c|}
\hline \multirow[t]{3}{*}{ Factor-price set: } & \multicolumn{2}{|c|}{$5 / 10 \mathrm{~d}$ at $6 \%$} & \multicolumn{2}{|c|}{$3 /-$ at $10 \%$} \\
\hline & \multicolumn{2}{|c|}{ Proportion of } & \multicolumn{2}{|c|}{ Proportion of } \\
\hline & $\begin{array}{l}\text { Revenues } \\
\text { (DB) }\end{array}$ & $\begin{array}{l}\text { Net returns } \\
\text { (DB-DPC) }\end{array}$ & $\begin{array}{l}\text { Revenues } \\
\text { (DB) }\end{array}$ & $\begin{array}{l}\text { Net returns } \\
(\mathrm{DB}-\mathrm{DPC})\end{array}$ \\
\hline $\begin{array}{l}\text { Tree crops } \\
\text { Cocoa } \\
\text { Rubber } \\
\text { Oil palm } \\
\text { Unirr. grapefruit }\end{array}$ & $\begin{array}{r}23.5 \\
9.4 \\
8.8 \\
5.6\end{array}$ & cent $\begin{array}{l} \\
44.42 \\
12.7 \\
13.4 \\
6.3\end{array}$ & $\begin{array}{r}20.8 \\
8.7 \\
8.0 \\
4.9\end{array}$ & $\begin{array}{r}38.9 \\
18.0 \\
12.3 \\
4.6\end{array}$ \\
\hline $\begin{array}{l}\text { Field crops } \\
\text { Cassava } \\
\text { Cowpeas } \\
\text { Maize } \\
\text { Rice } \\
\text { Sorghum }\end{array}$ & $\begin{array}{l}0.7 \\
1.1 \\
5.9 \\
0.6 \\
2.1\end{array}$ & $\begin{array}{l}2.4 \\
1.4 \\
4.9 \\
0.3 \\
0.9\end{array}$ & $\begin{array}{l}0.7 \\
1.2 \\
6.5 \\
0.6 \\
2.2\end{array}$ & $\begin{array}{l}3.1 \\
1.9 \\
7.0 \\
0.3 \\
0.7\end{array}$ \\
\hline \multirow[t]{2}{*}{$\begin{array}{l}\text { Livestock } \\
\text { Poultry } \\
\text { Cattle } \\
\text { Hogs }\end{array}$} & $\begin{array}{r}32.6 \\
3.2 \\
8.5\end{array}$ & $\begin{array}{l}5.4 \\
1.7 \\
6.4\end{array}$ & $\begin{array}{r}35.8 \\
3.5 \\
7.1\end{array}$ & $\begin{array}{l}5.4 \\
1.0 \\
6.9\end{array}$ \\
\hline & 100.0 & 100.0 & 100.0 & 100.0 \\
\hline
\end{tabular}

Source: calculations from Table I and from FAO Crop and Livestock Studies [3]. 
these price assumptions and their importance to estimates of settlement returns deserve closer examination.

Returns to cocoa on the settlement program are calculated on the assumption of a world price for cocoa of $£ 170$ per ton, a reasonably low price when compared to the market price in 1962, but one which seems very high indeed in the light of recent experience. The results of three alternative world-price assumptions on the present value of net settlement returns are shown in Table 5. The 2144-per-ton figure corresponds to the lowest price estimate derived from a series of projections for majorcommodity prices to 1970 made by the FAO [9, p. 39]..$^{15}$ At this price, cocoa, with a benefit-cost ratio of about 1.25 at either factor-price set, would remain a profitable component of settlement composition. The net returns from settlement production, however, would fall by about 25 percent, seriously reducing the net benefits generated to offset the social overheads involved in the program.

Table 5. Effect of cocoa prices on present value of net returns

\begin{tabular}{|c|c|c|}
\hline \multirow{3}{*}{ World price per ton } & \multicolumn{2}{|c|}{$\begin{array}{l}\text { Present value of net returns for settlements } \\
\qquad(\mathrm{DB}-\mathrm{DPC})\end{array}$} \\
\hline & \multicolumn{2}{|c|}{ Factor prices } \\
\hline & $6 \%$ interest rate & $10 \%$ interest rate \\
\hline $\begin{array}{l}£ 170 \\
£ 144 \\
£ 120\end{array}$ & $\begin{array}{c}\text { 5/10d per man-day } \\
£ 4.46 \text { million } \\
£ 3.27 \text { million } \\
£ 2.17 \text { million }\end{array}$ & $\begin{array}{l}\text { 3/- per man-day } \\
£ 2.81 \text { million } \\
£ 2.15 \text { million } \\
£ 1.55 \text { million }\end{array}$ \\
\hline $\begin{array}{l}\text { For comparison: present } \\
\text { value of settlement SOC }\end{array}$ & $£ 3.28$ million & $£ 3.04$ million \\
\hline
\end{tabular}

The fall in world cocoa prices during 1964-65, though hopefully temporary, somewhat weakens the credibility of the FAO projection. A world price of $\& 120$ per ton (the price actually reached in March 1965) would eliminate the net returns to cocoa production and would reduce the present value of net benefits to all settlement activities to about half of that expected with a \&170-per-ton price.

Expected returns to the settlement program are equally sensitive to the fortunes of egg prices. The only information upon which an assumed price of eggs could be based was the 5/- per dozen at which eggs from the pilot settlements were being sold to civil servants. Since the entire output

\footnotetext{
${ }^{15}$ Prices envisioned in these projections ranged from $\& 144$ per ton to $\& 240$, depending on the expansion of world supplies. At the $\& 240$ estimate, the present value of net returns to cocoa alone is 24 million, using the 6-percent rate of discount.
} 
of the settlement program could not be sold to this high-income market, an arbitrarily lower price of $3 / 6 \mathrm{~d}$ was assumed in calculating returns. But because of the widespread incorporation of poultry into the settlement units, a $6 \mathrm{~d}$ error in this assumption changes the present value of settlement net returns (to all activities) by approximately 25 percent at both the 6-percent and 10-percent rates of discount. Furthermore, though poultry is a crucial source of expected returns, its position as a component of the program is not very stable. At a 3/- price-one which is not unlikely in view of the plans for expanded production in the region and Nigerian preferences for eggs-the benefit-cost ratio to poultry raising would be below 1.0 and poultry would be dropped from the program unless production costs could be reduced.

Thus, examination of alternative price assumptions tends to weaken the positive estimate of project returns. The settlement program proves quite sensitive to the possibility of capital rationing and very sensitive to assumptions about the fortunes of cocoa and poultry. These assumptions themselves, on close examination, seem rather tenuous.

\section{Labor Costs and Settler Incomes}

The techniques of evaluation used in this appraisal require that a distinction be made between the social costs of settlement inputs and the distribution of incomes derived from the program. The measure of returns, which compares benefits to the program with estimated opportunity costs of resource inputs, need not reflect the ultimate distribution of revenues in the program; and when the actual distribution proposed for settlement returns is taken into account, a significant disparity arises between the opportunity cost estimated for the settler's labor and his expected income. The disparity has several implications in evaluating the opportunity cost of resources used in the program.

In this analysis two alternative estimates reflect the opportunity cost of labor: the 5/10d-per-man-day rate, which assumes that the wage to unskilled labor paid by the Western Region government is an accurate reflection of its scarcity, and the 3/- rate, corresponding to a lower estimate of opportunity cost. Labor inputs on the average settler's unit total about 450 man-days per year, ${ }^{16}$ so the annual labor incomes implied by these daily rates range from $£ 70$ to $£ 130$. Returns proposed for settlers in the program are much higher than this, ranging up to $£ 440$ per year. Unless the net returns to settlement production compare more favorably with overhead costs than they appear to in this analysis, the higher incomes of

\footnotetext{
${ }^{30}$ The labor requirements assume the presence of an extended family with more than one able-bodied farmer in the average settler's unit.
} 
settlers reflect an implicit subsidy to participants rather than higher productivity of the settlement form of organization.

The existence of such a subsidy does not directly affect the measurement of social returns to the program, which is somewhat independent of decisions made about the allocation of settlement incomes. But it must be remembered that the beneficiaries of the program will constitute only a very small proportion of the population engaged in agriculture in the region, and that any subsidy to them not justified by the direct productivity of the settlement program merely restricts the amount of government savings available for further agricultural development.

\section{Summary and Conclusions}

The purpose of this analysis has been to estimate social returns to the farm-settlement program and, by doing so, to examine whether the potential productivity of the Moshav form of organization justifies the rather large inputs of a social-overhead nature which it involves. While there is not sufficient information to provide totally satisfactory answers to these questions, the analysis does permit some generalization about the use of the settlement form of organization in the context of Western Nigeria's agriculture.

The estimate of expected project returns based on current price assumptions (Table 1) appears at first to resolve the argument over the returns and capital intensity with the conclusion that the program at least meets the minimum requirements set by the planners for investment components of the National Development Plan. Unfortunately this conclusion is seriously weakened when the price assumptions themselves are examined. On the factor-price side, it is seen that in the event of even moderate capital rationing the program cannot be justified without recourse to rather elusive indirect benefits. On the side of product prices, the flexibility attributed to the program from its varied composition is far less than would be expected. Social returns to the program-if not settler incomesrest heavily on the fortunes of two major items. One of these, cocoa, is already the Western Region's major export crop; the diverse composition of the settlement program is supposedly an attempt to reduce the impact of cocoa-price fluctuations. The other, commercial production of poultry, is somewhat experimental and involves implications of local consumption patterns and conditions of production which have not yet been fully explored.

When the actual mechanism for distribution of income from the settlements is taken into account, it is seen that the high annual incomes expected for participants are likely to result from an implicit government 
subsidy rather than from the increased productivity of the form of organization or producing techniques used. This subsidy involves several undesirable effects. It constitutes a restriction on government resources which could be used elsewhere to encourage the process of economic development, and it effects a regressive distribution of income by providing relatively high incomes to a few farmers with taxes collected from persons whose average incomes are lower. The form of imitation which this process is likely to elicit is that of demanding government subsidies for other groups of farmers rather than seeking higher incomes through means of increasing agricultural productivity.

Finally, it is necessary to raise one point which is hidden in this analysis, and which relates to the size of the "pilot" program of 13 settlements and the speed with which the program was brought into being. The size and diversity of the project adds another element of uncertainty-operating on the technical estimates of inputs and yields-to the estimates of costs and expected returns derived here. The administrative demands of a project of this scope are not small, and if they are not met, or are met insufficiently, the input costs per unit of output can far exceed those estimated. This can occur directly, as when breakdowns of procedures and schedules result in increased operating costs or lowered yields, or indirectly, through the increased absorption of scarce administrative talents to deal with such breakdowns. The decision to start a large number of settlements simultaneously means that the costs of learning how to operate the program will occur simultaneously on a number of settlements.

The tentative judgment which might be drawn from these conclusions is that the Moshav has been imported to Western Nigeria more as a form of organizational structure than a means of creating agricultural change in the region. The benefits of the Moshav form of organization, whatever they may be, do not appear in the form of dramatic increases in productivity which would clearly justify the social-overhead component of the investment or which would attract widespread emulation of the form of organization and producing techniques by other farmers. Less capital-intensive forms of cooperative-settlement units need to be considered as a means of introducing the benefits of the Moshav without the heavy organizational superstructure. Proposals for such units already exist and deserve further examination. ${ }^{17}$ Finally, ways of disseminating inputs in the agricultural sector to a larger proportion of farmers need also to be explored. The returns to overhead activities such as training farmers and providing information on new agricultural techniques might be much

\footnotetext{
${ }^{17}$ Among these is a program combining agricultural and small-scale industrial activities at an initial capital cost per settler lower than in the current settlement program [13].
} 
greater if they were not restricted to the relatively few farmers whom the type of settlement program described here can serve.

\section{Appendix}

\section{Examples of FAO Data and Benefit-Cost Analysis}

\section{Table A-1. Cocoa: FAO estimate costs and returns per acre}

\begin{tabular}{|c|c|c|c|c|}
\hline Year & $\begin{array}{l}\text { Labor: } \\
\text { man-days }\end{array}$ & $\begin{array}{l}\text { Total costs: } \\
\text { labor, tractor, } \\
\text { fertilizer }\end{array}$ & $\begin{array}{l}\text { Yield: } \\
\text { cwt. of } \\
\text { cocoa }\end{array}$ & $\begin{array}{l}\text { Revenue: } \\
\text { at } £ 4.50 \\
\text { per cwt. }\end{array}$ \\
\hline $\begin{array}{l}1 \\
2 \\
3 \\
4 \\
5 \\
6 \\
7 \\
8\end{array}$ & $\begin{array}{l}80 \\
25 \\
25 \\
25 \\
20 \\
24 \\
21 \\
23\end{array}$ & $\begin{array}{r}f 36.59 \\
13.01 \\
15.51 \\
15.15 \\
13.90 \\
19.24 \\
18.31 \\
20.23\end{array}$ & $\begin{array}{l}- \\
- \\
\frac{1}{2} \\
1 \\
2 \\
3 \\
4\end{array}$ & $\begin{array}{r}\bar{Z} \\
\text { E } \\
2.25 \\
4.50 \\
9.00 \\
13.50 \\
18.00\end{array}$ \\
\hline Total & & $£ 151.94$ & & $£ 47.25$ \\
\hline
\end{tabular}

II. Value of capital inputs: years 1-8

$\begin{array}{ll}\text { Costs } & £ 151.94 \\ \text { Less revenues } & -47.25 \\ & £ 104.69\end{array}$

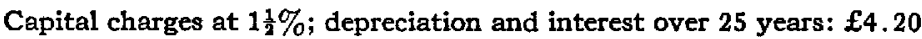

III. Full operation: years 10-34

Operating costs excluding labor

Depreciation and interest

$$
\begin{array}{r}
\$ 13.20 \\
4.20 \\
\hline-17.40
\end{array}
$$

Revenue $10 \mathrm{cwt}$. of cocoa

$$
45.00
$$

27.60

Residual return: labor and net returns

Labor time: 27 man-days at $5 / 10 \mathrm{~d}$

$-7.88$

Net returns above all costs

$$
\overline{£ 19.72}
$$

Source: FAO Team and Western Region (Nigeria) Ministry of Agriculture and Natural Resources, Crop Study: Cocoa, 1961.

. $20 \mathrm{cwt} .=1$ long ton (2240 lbs.) 
Table A-2. Cocoa: estimates of returns and benefit-cost ratios at $6 \%$ and $15 \%$

I. Basic assumptions about required inputs, costs, and outputs (from FAO data)

\begin{tabular}{|c|c|c|c|c|}
\hline Year & $\begin{array}{l}\text { Labor: } \\
\text { man-days }\end{array}$ & $\begin{array}{l}\text { Total costs: } \\
\text { labor, tractor, } \\
\text { fertilizer }\end{array}$ & $\begin{array}{l}\text { Yield: } \\
\text { cwt. of } \\
\text { cocoa }\end{array}$ & $\begin{array}{l}\text { Revenue } \\
\text { at } £ 4.50 \\
\text { per cwt. }\end{array}$ \\
\hline $\begin{array}{c}1 \\
2 \\
3 \\
4 \\
5 \\
6 \\
7 \\
8 \\
9 \\
10-30 \\
31 \\
32\end{array}$ & $\begin{array}{l}80 \\
25 \\
25 \\
25 \\
20 \\
24 \\
21 \\
23 \\
27 \\
27 \\
27 \\
27\end{array}$ & $\begin{array}{r}£ 36.59 \\
13.01 \\
15.51 \\
15.19 \\
13.90 \\
19.24 \\
18.32 \\
20.24 \\
20.71 \\
20.71 \\
20.71 \\
20.71\end{array}$ & $\begin{array}{r}\frac{1}{3} \\
1 \\
2 \\
3 \\
4 \\
7 \\
10 \\
8 \\
6\end{array}$ & $\begin{array}{r}f 2.25 \\
4.50 \\
9.00 \\
13.50 \\
18.00 \\
31.50 \\
45.00 \\
36.00 \\
27.00\end{array}$ \\
\hline \multicolumn{3}{|c|}{$\begin{array}{l}\text { II. Present values, start of year } 1 \\
\text { (1) Benefits, years 1-32 } \\
\text { (2) Costs, years 1-32 }\end{array}$} & $\begin{array}{c}6 \% \\
£ 373.85 \\
£ 299.34\end{array}$ & $\begin{array}{r}15 \% \\
£ 108.87 \\
£ 152.76\end{array}$ \\
\hline \multicolumn{3}{|c|}{ III. Benefit-cost ratio. } & 1.25 & .71 \\
\hline
\end{tabular}

Source: information in Table A-1.

\section{References}

[1] Chenery, H. B., “The Application of Investment Criteria," Quart. J. Econ. 77:56-86, Feb. 1963.

[2] FAO Team and Western Region (Nigeria) Ministry of Agriculture and Natural Resources, Agricultural and Farm Management Plans, 1961-62, mimeo.

[3] — Crop and Livestock Studies, 1961-62, mimeo.

[4] Gallettr, R., K. D. S. Baldwin, and I. O. Dina, Nigerian Cocoa Farmers: A Study of Yoruba Cocoa Farming Families, London, Oxford University Press, 1956.

[5] Krainen, Mordechai E., "The Introduction of Israel's Land Settlement Plan to Nigeria," J. Farm Econ. 45:535-546, Aug. 1963.

[6] —- Israel and Africa: A Study in Technical Cooperation, New York, Frederick A. Praeger Publishers, 1964.

[7] McKean, Roland N., Efficiency in Government Through Operations Analysis, New York, John Wiley \& Sons, Inc., 1958.

[8] STOLPER, W. F., "The Main Features of the 1962-68 National Plan," Nigerian J. Econ. and Soc. Stud., July 1962, pp. 85-91.

[9] United Nations, Food and Agriculture Organization, Agricultural Commodities, Projections for 1970, 1962.

[10] Wells, Jerome C., An Appraisal of Agricultural Investments in the 1962-68 Nigerian Development Program, unpublished Ph.D. thesis, University of Michigan, 1964.

[11] ㄴ., "Appraising an Agricultural Project in Northern Nigeria: A Problem in Investment Evaluation," Nigerian J. Econ. and Soc. Stud., March 1963, pp. 127-140.

[12] — "Investment Criteria and the Nigerian Development Plan," Nigerian J. Econ. and Soc. Stud., Nov. 1964, pp. 277-307.

[13] Western Nigeria, Government of, White Paper on Integrated Rural Development, Official Document No. 8 of 1963. 